\title{
Race to the Bottom: \\ Low Productivity, Market Power, and Lagging Wages
}

\author{
Lance Taylor and Özlem Ömer*
}

\author{
Working Paper No. 80
}

August 8, 2018

\begin{abstract}
"Dualism" in the structure of production across sectors of the US economy, employment by sector, productivity levels and growth, real wages, and intersectoral terms-of trade increased markedly between 1990 and 2016. The discussion focuses on 16 sectors. Seven were "stagnant" - construction, education and health, other services, entertainment, accommodation and food, business services, and transportation and warehousing. They had low productivity levels, productivity growth rates hovering around zero, and low real wages. Their share of total employment rose from $47 \%$ in 1990 to $61 \%$ in 2016 . The other "dynamic" sectors had higher and positively growing productivity while the terms-of- trade shifted against them. This bifurcation between industries is discussed in terms of a simple model. Increasing duality and secular stagnation are distinct possibilities.
\end{abstract}

\footnotetext{
* New School for Social Research. Support from the Institute for New Economic Thinking (INET) and comments by Thomas Ferguson, Duncan Foley, Codrina Rada, and Servaas Storm are gratefully acknowledged.
} 
Keywords: economic dualism, industrial structure, productivity, low wages, employment

JEL Codes: D31, D33,E2, E12, E24, J40, L11 
Output, employment, and income flows in the American economy became strikingly more unbalanced over recent decades. In an old description from development economics, a "dual economy" emerged, signaled by divergence between "stagnant" and "dynamic" sectors in the structure of production, growing employment in stagnant industries, and rapidly rising inequality in the functional and size distributions of income. Following INET-sponsored research by Temin (2015) and Storm (2017), this paper takes a look at how the American dual economy has evolved since 1990 when relevant data sets become available, and tries to assess the major drivers.

The first topic is how production and distribution across industries or "sectors" of the economy interact. Diagrams and numbers show the evolution of sectoral levels and growth of real wages and labor "productivity," a name for a widely discussed ratio,

Productivity $=$ Real output $\div$ Employment.

Productivity is an accounting relationship that links output, employment, and distribution. It is tricky to apply. Complications are discussed below. ${ }^{1}$ We then turn to shifts in intersectoral relative prices or the terms-of-trade between sectors. An explanatory framework is proposed, drawing on insights from development economics and simple structuralist macro models.

In a common disaggregation, 16 producing sectors are used to illustrate structural change. Compared to the others, seven sectors -- construction, education and health along with other services (their two dots overlap), entertainment, accommodation and food, business services, and transportation and warehousing -- have low levels of productivity. Their growth rates of productivity and real wages lagged the rest. Their share of total employment rose from $47 \%$ in 1990 to $61 \%$ in 2016 while their share in wages went from $57 \%$ to $56 \%$ of the total. Despite their high employment and output, they generated only $30 \%$ of total profits at the beginning of the period and $23 \%$ at the end. Except for construction and transport, the shares of their own profits in output declined.

The drastic fall in the share of wages relative to employment demonstrates visible wage retardation. Their real output share fell from $48 \%$ to $41 \%$. This shift of labor toward low wage, low productivity jobs helps explain the striking increase of American income inequality.

${ }^{1}$ In the jargon, real output is measured as double-deflated chain-indexed value-added, with data from the US Bureau of Economic Analysis (BEA). Annual employment levels are provided by the Bureau of Labor Statistics (BLS). The ins and outs of double deflation and chain indexing are set out in Moyer, et. al. (2004) from the BEA. 


\section{Increasing imbalances}

Figure 1 begins to tell the tale. Productivity growth rates 1990-2016 are displayed along the horizontal axis. The seven lagging sectors had rates hovering around zero. Figure 2 shows that these sectors along with retail trade and agriculture have productivity levels less than $\$ 100,000$ per employed person per year (or roughly $\$ 55$ per hour) in prices of 2009 . Table 1 shows that the seven accounted for $46.8 \%$ of total employment in 1990 and $60.8 \%$ in 2016 - the proportion of down-market jobs shot up.

\section{Figure 1 here}

\section{Figure 2 here}

Growth rates of real wages are plotted along the vertical axis in Figure $1 .^{2}$ The rates for the bottom sectors were dismal - all less than one percent per year and four negative (see Table 1). The slope of a trend line through the points (or the cross-sectional elasticity of wage growth with respect to productivity growth) is 0.6 . There was a substantial wage lag.

\section{Table 1 here}

The other sectors have higher productivity levels and/or growth. As noted above, retail and agriculture have relatively low productivity but respectable growth. Utilities have high productivity combined with slow growth. Finance and insurance (FI), manufacturing, wholesale, information, and mining have solid performances on both counts. Real estate rental and leasing has exceptionally high measured productivity. The real estate business collects fees and rents, which flow into a profit share of value-added exceeding $90 \%$, but it does not create many jobs. It is basically an outlier. Computers and electronics comprise a sub-sector of manufacturing included to illustrate the properties of a relatively small but leading branch of the economy.

\footnotetext{
${ }^{2}$ The growth rates refer to "product wages" or the costs of labor to business. They were estimated as current value wage shares of value-added times real labor productivity levels. The numbers are close to independent estimates of real wages. To give an example in round numbers, the end-of-period wage share in manufacturing was around 0.47 . Productivity was $\$ 150$ thousand, giving a wage of $\$ 70$ thousand per employee.
} 
Ignoring real estate and computers, the trend line though the other sectors has a slope of 0.65. Bringing in the outliers gives a slope of 1.05. Either way, even the dynamic sectors demonstrate a lag of overall wage payments behind productivity. The fact that labor payments did not keep up with productivity across almost all sectors suggests that generalized wage suppression rather than price increases due to business monopoly was the key factor in making the income distribution become more unequal. ${ }^{3}$

A complicating factor enters in the form of an idea tracing at least back to Marx and inserted into mainstream economics by Hicks (1932). Businesses can reduce labor costs by cutting wages or increasing productivity. If they succeed with wage suppression then there is less incentive for productivity-increasing innovation. Along with other linkages discussed below, this feedback can worsen economic stagnation.

Most dynamic sectors (but not agriculture and retail) had relatively high end-of-period wage levels. Shares of their wage payments in the total typically exceeded their shares in employment. The opposite is true for the stagnant sectors, with business services (a mixed bag of enterprises ranging from call centers through collection agencies to credit bureaus and high end management consulting, etc.) as the main exception.

\section{Dual economy}

Employment shares can be used to make a stab at estimating the size of the dual economy. If more lucrative occupations from business services are excluded from the $61 \%$ share of the seven sectors while low wage workers in agriculture and retail trade are brought in, then the size of the stagnant zone of the economy might fall toward 45-50\% -- still dismayingly high numbers.

There is also the question of the sizes of the shares of sectoral value-added flows appropriated by the middle class (say households between the $61^{\text {st }}$ and $99^{\text {th }}$ percentiles of the size distribution who rely largely on labor income) and the top one percent. Setting up a spreadsheet showing how value-added by sector is spread across its payments to households is far beyond the scope of this paper. But we can observe that in prices of 2014 economy-wide mean labor compensation per household in the bottom $60 \%$ was in the range of $\$ 30,000$, below the estimates

\footnotetext{
${ }^{3}$ See further discussion below and Taylor and Ömer (2018).
} 
for the stagnant sectors of average wages in prices of 2009 per employee in Table $1^{4}$ (Taylor, forthcoming). It appears that the bottom tier of households may well derive labor incomes from stagnant sectors in which wages are already low. One might add that for the bottom $60 \%$ transfer income is almost as big as labor compensation. ${ }^{5}$ If dualism is interpreted as referring only to household incomes, then perhaps one-third of recipients might be in the dual economy still a very high proportion.

Tables $2 \mathrm{a}$ and $2 \mathrm{~b}$ shed additional light on the duality question. In Taylor (forthcoming) distributional data from the well-known Congressional Budget Office (CBO, 2018) study of the size distribution of income are rescaled to fit the national accounts. Four sources of income for households include (i) labor compensation ("wages"); (ii) non-wage incomes including imputed rents on owner-occupied housing, proprietors' incomes, and depreciation; (iii) fiscal transfers (Social Security, Medicare, Medicaid, etc.); (iv) and interest and dividends paid via the financial sector.

Data on flows of household incomes at different levels generated by productive sectors are not readily available. Tables $2 \mathrm{a}$ and $2 \mathrm{~b}$ present a very rough approximation for three income strata - the bottom $60 \%$ of households ("low"), households between the $61^{\text {st }}$ and $99^{\text {th }}$ percentiles ("middle") and the top one percent ("high").

For the lower two groups, we split households between stagnant and dynamic sectors according to their different sources of incomes (not splitting the top group because it mainly relies on non-wage and financial incomes). We separated income from employment between sectors using the stagnant wage share mentioned above. Non-wage income was split using the output share. The employment share was used for fiscal and financial transfers. The resulting macro level flows in trillions of dollars in prices of 2014 appear in Table 2a.

\section{Table 2a}

\footnotetext{
${ }^{4}$ The mean for middle class households is around $\$ 120,000$ and over $\$ 500,000$ for the top one percent. The share of unemployed persons in lower income households (disproportionately female, minority, or young) is relatively high.

${ }^{5}$ In line with overall dualization of the economy, for the bottom three quintiles of the size distribution the ratio of government transfers to wage income rose from around one-third in the mid-1980s to near equality in the present decade. Most of this change was due to rising transfers while wage income grew slightly.
} 
All the numbers are large, but differences among sectors and households already begin to appear. The top one percent do not receive significant fiscal transfers, while the bottom level households do. Wage income for the middle group exceeds the flow to the bottom, and they also get visible incomes from other sources. Table $2 \mathrm{~b}$ highlights these distinctions by presenting incomes per household.

\section{Table 2b}

With due regard to all the assumptions used to construct the table, it appears that households in the lower income group who are active in the stagnant sector are visibly worse off than their counterparts in the dynamic part of the economy. In other words, dualism shows up most strongly for the least well-to-do. The middle group is also subject to dualism, mainly in wage incomes. The top one percent is exempt. The wave of redistribution for the working classes shown in Table 1 did not reach higher income households who largely rely on proprietors' incomes and financial transfers generated by profits. Households in the stagnant zone were the most hard hit.

\section{Productivity growth}

The next question is how trends in productivity helped produce this situation.

Productivity growth (higher output per unit of labor) is often credited to "technological progress" due to reorganization of production, more efficient capital goods, or better use of capital. Of course, technical change takes place within the overall socioeconomic context. ${ }^{6}$ In practice it may arise from greater labor exploitation or sharper competitive practices on the part of business. Going in the opposite direction, as discussed below, falling productivity may provide a vehicle for accommodating surplus labor. Following models proposed by Rada (2007) and Storm (2017) we will see how it adjusts to employment imbalances between stagnant and dynamic sectors

\footnotetext{
${ }^{6}$ For example, the "central dogma" of ecological economics is that the ratio of (mostly fossil fuel) energy use to employment rises in direct proportion to productivity - in the data, the relevant elasticity is equal to one (Semieniuk, 2018). Changing technology played a role but the entire means of production evolved to support this relationship.
} 
"Value-added" is the standard metric for output. The numbers used herein are subject to index number complications. As noted above, yearly levels of "real" value-added are estimated by “double deflation." A sector's gross output (including intermediate inputs) in current prices is deflated by an "appropriate" price index. The value of the intermediates deflated by another index is then subtracted to generate real value-added. Yearly estimates are strung together using a "chain index" (with varying weights over time) to produce a time series. ${ }^{78}$

Figure 3 shows how sectoral productivity levels evolved over time. Several points stand out, especially in light of recent debate about the extent to which rising business monopoly power has led to more income inequality.

\section{Figure 3}

One observation is that aside from business services in panel B, the stagnant sectors are grouped in the low productivity panels C and D. Along with business services, they show sluggish or negative productivity growth combined with rising employment. One is tempted to assume that holding down productivity was a means for business to create low end, low wage jobs for workers evicted from high productivity sectors. Productivity did rise in retail, a large low-wage employer. Its employment share fell as demand growth did not offset its productivity increases.

In the high productivity panel A, all four output/employment ratios grew. Real estate rental and leasing as noted above is an outlier. The utility and mining sectors are traditionally assumed to include "natural" monopolies, while information has privileged access to data that it

${ }^{7}$ In a bit more detail, a sector's total cost can be broken down into costs of intermediate inputs and valueadded. Double deflation treats real value-added as a residual and so focuses on the interindustry structure of production. Current price estimates tend to estimate levels of output and value-added directly, making intermediate costs the residuals. Double deflation is less reliable for a sector when it is difficult to estimate the value of its output directly from market transactions. Simply adding up costs to determine output then becomes unavoidable. Education may be the most important example. It almost certainly has low productivity growth, but the estimate of $-0.56 \%$ per year for education and health in Table 1 is imprecise.

${ }^{8}$ In a hot topic at the moment double deflation can also be used to calculate movements in "effective protection" of real wages and profits induced by changes in tariffs on a sector's output and intermediate inputs, e.g. pressures on the automobile sector due to higher tariffs for steel, possibly offset by tariffs on imported car parts and cars. 
can exploit. In panel B, finance and insurance also has monopoly elements. The diverse manufacturing sector has historically depended on continuing productivity growth; wholesale trade has benefitted from advances in inventory control.

Debate rages about whether the observed excess of productivity over wage growth is due to business "monopoly" power pushing prices up against wages or suppression of wages resulting from labor's failing bargaining power. Decreasing profit shares suggest that monopoly is not rampant in stagnating sectors. Among the dynamic sectors real estate rental and leasing accounts for a stable $30 \%$ of total profits. Property owners no doubt wield market power, but it does not appear to have strengthened over time. Manufacturing and information together account for a quarter of profits and wholesale and retail trade for another one-eighth. As noted above, these large profits flow mostly to high income households, leading to rising income inequality.

The bottom line, perhaps, is that productivity increases may have gone along with monopoly power in dynamic sectors (and some sub-sectors). Productivity growth did not accelerate, suggesting that increased monopoly did not play a role. In panels C and D, employment increases may provide a better explanation than monopoly for slow or negative productivity growth and the wage lag. In a relevant illustration, Montier and Pilkington (2017) point out that the US productivity soared during WW II and collapsed thereafter, precisely in line with its definition as a ratio of independently driven numbers including the size of the available civilian labor force in the denominator.

Across the 16 sectors, overall productivity growth can be decomposed into a weighted average of own-rates of increase and "reallocation" effects due to labor movements. ${ }^{9}$ For instance, an increase in employment in a low productivity sector reduces economy-wide productivity growth.

Figure 4 presents the sectoral contributions. Toward the right, job growth in education and health, and accommodation and food cuts visibly into overall productivity. Toward the left, real estate and manufacturing have real output shares in the range of 12-15\% and make strong productivity contributions. Shares of finance and insurance, retail, wholesale, and information cluster above five percent. Table 1 shows that all these sectors had visible own-productivity

\footnotetext{
${ }^{9}$ The weights are sectoral shares in output for productivity growth and differences between output and employment shares for growth of employment. If its output share exceeds its employment share, a sector has relatively high productivity so that if its employment rises there is a positive contribution to overall productivity growth.
} 
growth, explaining the pattern in Figure 4. Business services is a large sector at around $15 \%$ but its slow own-productivity growth means that it did not contribute very much economy-wide.

\section{Figure 4 here}

\section{Employment growth}

Productivity shifts provide a means to explore movements in overall employment. At the aggregate level, is true that

$$
\text { Employment } \div \text { Population }=(\text { Output } \div \text { Population }) \div(\text { Output } \div \text { Employment })
$$

or

$$
\text { Employment ratio }=\text { Output per capita } \div \text { Productivity } .
$$

This formula provides the basis for a decomposition of growth in the employment ratio over time as a weighted average of growth rates of sectoral outputs per capita minus growth rates of productivity. The weights are sectoral employment shares. Using working age population for convenience, Figure 5a presents the results.

\section{Figure 5a here}

In the relatively large manufacturing sector, productivity growth outstripped demand growth, so jobs were destroyed. There was a rough balance in the other sectors toward the left. Demand growth along with stagnant productivity led to job creation in business services and accommodation and food. Both demand expansion and falling productivity pushed up employment in education and health.

Figure $5 \mathrm{~b}$ shows the combined effects on the employment ratio of output and productivity changes. The bulk of job creation took place in the seven sectors pointed out above (and grouped toward the bottom of Table 1). In increasing order, job annihilation took place in information, wholesale, retail, agriculture, and manufacturing. Robotization, the latest manifestation of the trend toward automation that has run for more than two centuries, no doubt contributed to slower job growth, mostly by blocking young entrants into the industrial labor force. 
Notably, there are 36 weekly employment hours for business services; education and health, 33; and accommodation and food, 26. Manufacturing has 41 weekly hours. In effect jobs shifted toward sectors with both low wages and short hours. ${ }^{10}$

\section{Figure 5b here}

\section{Terms of trade}

Given the way the numbers are calculated, the main signal that a sector is enjoying productivity growth is that the current price value of its "real" output is falling relative to the rest of the economy. In other words, its "terms of trade" are deteriorating. The terms of trade will shift in favor of a sector with lagging productivity in line with the "Baumol effect" (Baumol and Bowen, 1966). ${ }^{11}$ Automobiles have become relatively less expensive over time while the cost of health care has gone up

The last column of Table 1 shows sectoral growth rates of double-deflated, chain-indexed value-added. One immediate observation is that manufacturing grew less rapidly than other sectors, e.g. its own computer and electronics sub-sector, information, wholesale and retail trade, and finance and insurance. Slower output growth in manufacturing is to be expected in light of historical experience worldwide. ${ }^{12}$

Sectoral real growth rates can be compared to the rates shown in the second-last column, which were calculated by deflating value-added in current prices by an overall price index called the GDP deflator. Differences between the two columns reflect productivity trends. The lagging seven sectors at the bottom of the table all had (deflated) current price growth rates that exceeded

\footnotetext{
${ }^{10}$ One might add "and multiple jobs..." About five percent of US workers hold more than one job, with the number apparently rising.

${ }^{11}$ The "effect" is often interpreted as stating that real wages tend to rise in industries with slow productivity growth, pushing up costs. For the data summarized in Table 1, this version of Baumol's idea is not true. It can be rejected on accounting grounds alone. The real (product) wage equals labor productivity times the wage share. Such shares are relatively stable so that growth of the wage will be roughly proportional to growth of productivity. The fact that in Table 1 wages lag productivity in low end sectors means that profits have benefitted most from Baumol effects.

${ }^{12}$ In European examples according to World Bank data, the manufacturing share of real GDP in Germany fell from $25 \%$ in 1991 to $21 \%$ in 2017, and in Sweden from 21\% in 1980 to $14 \%$ in 2016. The decrease in the USA was from $16 \%$ in 1997 to $12 \%$ in 2016.
} 
their real rates. The implication is that prices shifted in their favor. With a few exceptions, the opposite is true of the remaining sectors. The real vs. current price growth rate differential for computers is particularly striking. ${ }^{13}$

\section{Stagnant and dynamic sectors}

The evidence shows that the seven sectors toward the bottom of Table 1 fall behind in profits , labor income, and output while creating employment. The ones toward the top of the table have high and rising productivity, albeit with real wage suppression. Models of interactions between "dynamic" and "stagnant" sectors proposed by Rada (2007) and Storm (2017) help explain the discrepancy.

Both papers assume that workers who do not find dynamic sector jobs are driven into the stagnant part of the economy. To paraphrase Storm for rich economies, especially the USA, this "full employment" assumption reflects the fact that in the absence of unemployment insurance and social security worth the name, workers must find jobs, if not in the better paid core, then in a low end sector in some peripheral activity. In contrast to standard models, endogenous adjustment of productivity in the stagnant sector allows "full" employment (supplemented by fiscal transfers) to be maintained.

This idea traces back to debates in development economics a half-century ago. Lewis (1954) proposed that poor countries have "surplus labor" (or a "reserve army" in Marx's terminology) which can be brought from subsistence activity into employment in an expanding modern sector. Sen (1966) pointed out that subsistence output would change very little as labor moved in and out of the sector. In a reversed version of Lewis's narrative, Sen's idea suggests that productivity should fall in proportion to the quantity of labor moving into the stagnant zone, or that the elasticity of productivity with respect to employment equals minus one, in a strong case of decreasing returns. Slow productivity growth in the face of rising employment for the

\footnotetext{
${ }^{13}$ On the assumption that prices are largely driven by labor costs, the older literature on international trade traced shifts in the "double factorial terms of trade" to differences between wage growth minus productivity growth across countries. In the current context if wage growth rates are equal, a negative difference of this indicator between dynamic and stagnant sectors arises if productivity growth is higher in the former than the latter (as in Table 1). That is, prices shift against the dynamic sectors due to productivity growth differentials.
} 
stagnant sectors in Table 1 indicates that this pattern applies today, although the magnitude of the relevant (negative) "Sen elasticity" would be difficult to quantify. ${ }^{14}$

Another model originally proposed in the 1960s and published by Kaldor (1978) suggests that in the dynamic part of the economy, the growth rate of productivity may respond positively to the growth rate of output. Can this linkage create jobs?

To answer the question, we have to look at the impacts of a productivity increase at an initial level of output. Because

\section{Unit labor cost $=$ Real wage $\div$ Productivity}

labor becomes cheaper, pushing up profits and stimulating investment as well as making "our" exports more competitive. Via both channels aggregate demand may rise.

At the same time, because

$$
\text { Employment }=\text { Output } \div \text { Productivity }
$$

jobs are destroyed and labor income falls, reducing consumption demand. In the jargon, if higher investment and exports more than offset lower consumption, the economy is said to be "profitled;" otherwise it is "wage-led." Two further points are:

(i) The final outcome may generate more jobs than before the productivity increase if the system is "strongly" profit-led. Employment will definitely decrease when demand is wage-led.

(ii) In countries that are members of the OECD (including the USA) expenditure survey data suggest that savings rates are negative for low income households which rely roughly halfand-half on wage and transfer income. If the income shift from wages to profits mostly damages middle class households (with, say, higher than median incomes mostly coming from wages) then aggregate demand may be both profit- and low income-led.

Whether the US economy is wage or profit-led is controversial. But it surely is not strongly enough profit-led for a productivity increase to raise employment. In other words, faster productivity growth in the dynamic sector forces workers to move to the stagnant zone in which firms adjust by using more workers to produce the same real output.

\footnotetext{
${ }^{14}$ For activities like education and health the elasticity's absolute value might even be greater than one.
} 
The next question is how strong are feedbacks from the stagnant to dynamic sectors? Figure 6 illustrates.

\section{Figure 6 here}

The "Employment" schedule shows that a change in the growth rate of dynamic sector employment must be met by an offsetting shift in the growth of stagnant sector jobs (the slope depends on employment shares). The system must adjust along the schedule on the full employment assumption.

The "Demand" curve shows how strongly income generated by faster growth of stagnant sector jobs stimulates employment growth in the dynamic sector. The Sen elasticity and the response of stagnant sector real wages to productivity both affect this response. The schedule may be steep if there is relatively weak feedback of stagnant sector employment onto demand for dynamic sector goods and services.

A jump in dynamic sector productivity growth shifts the demand schedule to left, moving the economy from point A to B. Employment is pushed into the stagnant sector, forcing down productivity there. The initial sectoral imbalance gets worse. As employment is pushed out of the dynamic sector, moreover, demand generated by low-wage workers in the stagnant zone will drop off and the schedule may shift further to the left. This movement itself can be a major source of secular stagnation.

In terms of "policy" as usually interpreted, there is a limited menu of interventions that can be used to move the system from B back toward A. One could be based on fiscal or monetary expansion to push up demand for dynamic sector goods and services, pulling jobs from the stagnant sectors. The practical problem is that although among policy-makers faith in “expansionary austerity" may be weakening, it has certainly not disappeared.

If the economy is, in fact, low income-led, policies aimed at redistributing income toward the lower deciles of the size distribution would have a similar effect. The recent American tax "reform" of course went in the opposite direction. Incomes policies could be used to stimulate wage growth in stagnant sectors relative to increases in the dynamic part of the economy. These and similar adjustments could be helpful but fail to address more fundamental structural problems. For example, low positive or negative productivity growth, however measured, in the 
dysfunctional American health care system is devastating. Employment in manufacturing, historically the main locus of productivity growth, will probably remain weak. Income elasticities of demand for the whole range of manufactured final goods (or "stuff") and even intermediates are not likely to rebound even as productivity growth continues. Globalization and international trade have taken a toll in terms of jobs, not only in manufacturing. Offshoring the production of intermediate inputs such as computer code cuts costs and raises the productivity of remaining workers in the USA. Creative destruction of onshore jobs still is destruction. Its impact may be stronger if investment in new technologies shifts from the USA to abroad.

Falling or stable wages in stagnant sectors is exacerbated by non-poaching and noncompetition clauses in contracts (which restrict job opportunities outside a company for a worker who leaves it). Divide-and-rule employment tactics in a "fissuring" labor market as described by Weil (2014) are another aspect of this process.

All these factors tend to push the demand schedule in Figure 6 to the left. There are countervailing powers but stagnation may well worsen unless they soon grow stronger. 


\section{References}

Baumol, William, and William Bowen (1966) Performing Arts: The Economic Dilemma, New York: Twentieth Century Fund.

Congressional Budget Office (2018) “The Distribution of Household Income, 2014” https://www.cbo.gov/publication/53597

Hicks, John R. (1932) The Theory of Wages, London: Macmillan

Kaldor, Nicholas (1978) "Causes of the Slow Rate of Growth of the United Kingdom" in Further Essays on Economic Theory, London: Duckworth

Lewis, W. Arthur (1954) "Economic Development with Unlimited Supplies of Labor," Manchester School, 22: 139-19.

Montier, James, and Philip Pilkington (2017) “The Deep Causes of Secular Stagnation and the Rise of Populism," GMO White Paper (Grantham, Mayo, Van Otterloo)

Moyer, Brian C., Mark A. Planting, Mahnaz Fahim-Nader, and Sherlene K. S. Lum (2004) "Preview of the Comprehensive Revision of the Annual Industry Accounts, https://www.bea.gov/scb/pdf/2004/03March/0304IndustryAcctsV3.pdf

Rada, Codrina (2007) “A Growth Model for a Two-Sector Economy with Endogenous Employment," Cambridge Journal of Economics, 31: 711-740

Semieniuk, Gregor (2018), "Energy in Economic Growth: Is Faster Growth Greener?" SOAS Department of Economics Working Paper Series, No. 208, SOAS University of London.

Sen, Amartya (1966) "Peasants and Dualism with and without Surplus Labor," Journal of Political Economy, 74: 425-450.

Storm, Servaas (2017) "The New Normal: Demand, Secular Stagnation, and the Vanishing Middle-Class," https:/www.ineteconomics.org/uploads/papers/WP_55-Storm-The-NewNormal.pdf

Taylor, Lance, and Özlem Ömer (2018) "Where do Profits and Jobs Come From? Employment and Distribution in the US Economy," https://www.ineteconomics.org/uploads/papers/WP_72-Taylor-and-Omer-April-8.pdf

Taylor, Lance (forthcoming) The Rise of the Rentier: Soaring Economic Inequality from Reagan to Trump and What is to be Done, New School for Social Research

Temin, Peter (2017) The Vanishing Middle Class: Prejudice and Power in a Dual Economy, Cambridge MA: MIT Press

Weil, David (2014) The Fissured Workplace, Cambridge MA: Harvard University Press. 
Figure 1: Productivity growth vs product wage growth 1990-2016 (trend lines omit real estate and computers)

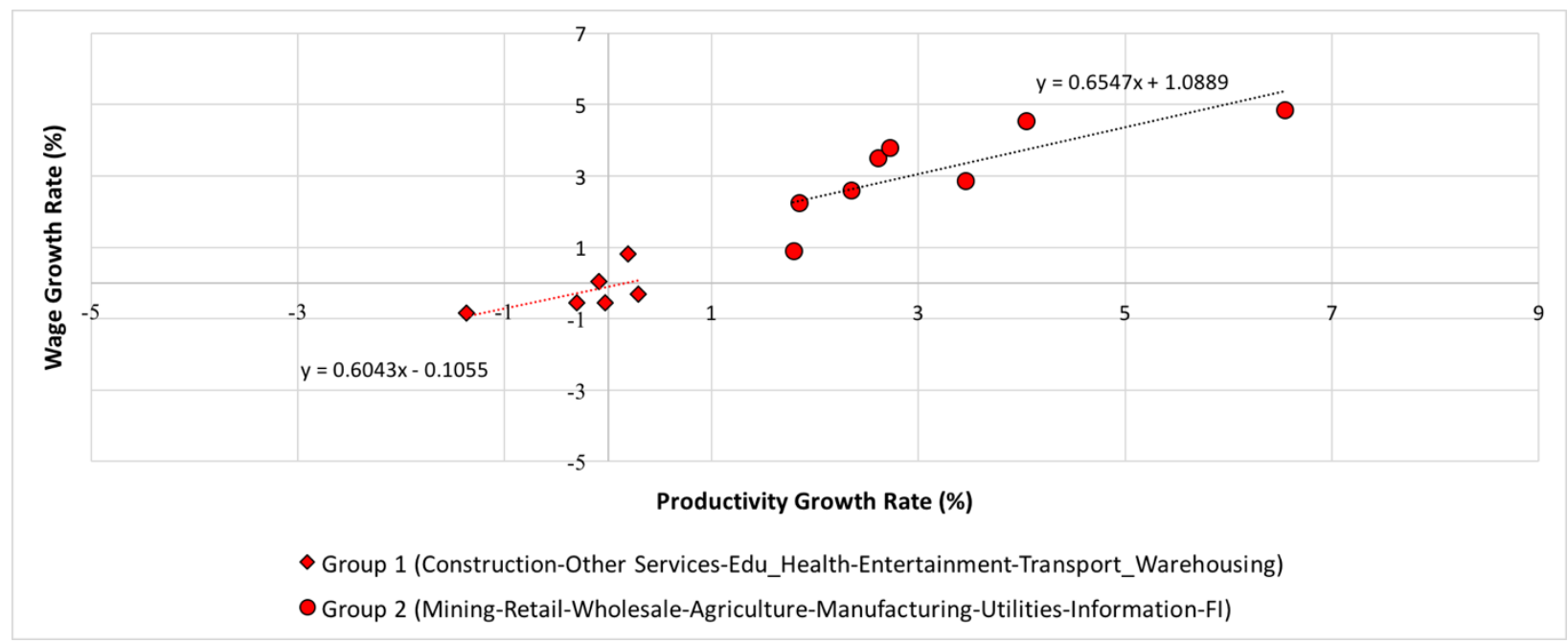

Figure 2: Productivity levels vs. growth rates 1990-2016

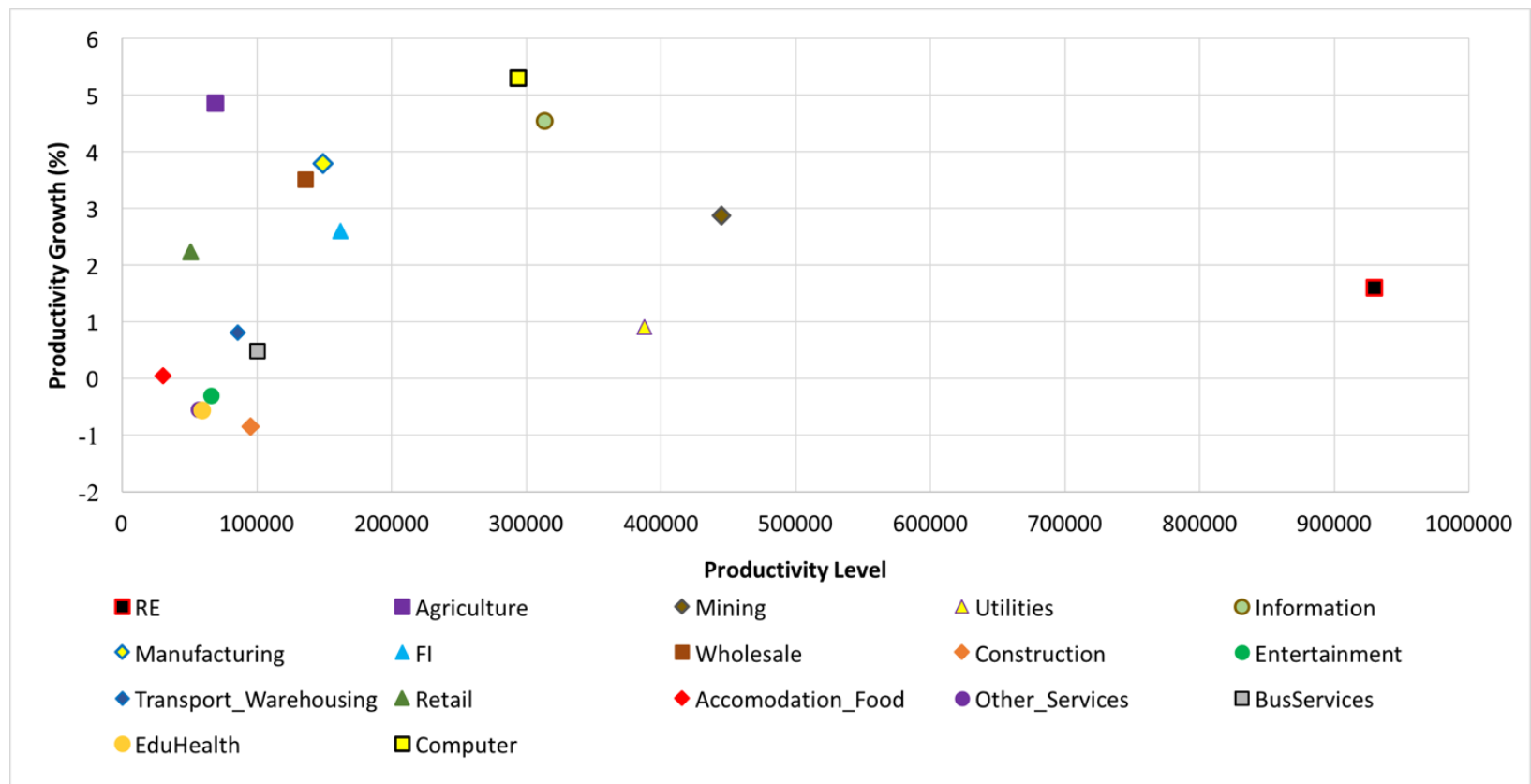


Table 1: Summary data for the sectors

\begin{tabular}{|c|c|c|c|c|c|c|c|c|c|c|c|c|c|c|}
\hline \multirow{2}{*}{ SECTORS } & \multicolumn{3}{|c|}{ PRODUCTIVITY GROWTH RATE (\%) } & \multicolumn{3}{|c|}{$\begin{array}{c}\text { REAL WAGE (per employee) GROWH } \\
\text { RATE (\%) }\end{array}$} & \multicolumn{2}{|c|}{$\begin{array}{l}\text { REAL WAGE LEVEL } \\
\text { (Total thousands of } \$ \text { ) }\end{array}$} & \multicolumn{2}{|c|}{$\begin{array}{l}\text { EMPLOYMENT } \\
\text { SHARE }(\%)\end{array}$} & \multicolumn{2}{|c|}{$\begin{array}{l}\text { REAL WAGE SHARES IN } \\
\text { TOTAL (\%) }\end{array}$} & \multirow{2}{*}{$\begin{array}{c}\begin{array}{c}\text { OUTPUT } \\
\text { Growth } \\
\text { (Current \%) }\end{array} \\
\begin{array}{c}\text { AVERAGE } \\
\text { (1991-2016) }\end{array}\end{array}$} & \multirow{2}{*}{$\begin{array}{c}\text { OUTPUT } \\
\text { Growth (Real } \\
\%)\end{array}$} \\
\hline & INITIAL (1991) & FINAL (2016) & $\begin{array}{c}\text { AVERAGE } \\
\text { (1990-2016) }\end{array}$ & $\begin{array}{l}\text { INITIAL } \\
\text { (1991) }\end{array}$ & $\begin{array}{l}\text { FINAL } \\
\text { (2016) }\end{array}$ & $\begin{array}{c}\text { AVERAGE } \\
\text { (1990-2016) }\end{array}$ & $\begin{array}{l}\text { INITIAL } \\
\text { (1990) }\end{array}$ & $\begin{array}{l}\text { FINAL } \\
\text { (2016) }\end{array}$ & $\begin{array}{l}\text { INITIAL } \\
\text { (1990) }\end{array}$ & $\begin{array}{l}\text { FINAL } \\
\text { (2016) }\end{array}$ & $\begin{array}{l}\text { INITIAL } \\
\text { (1990) }\end{array}$ & $\begin{array}{l}\text { FINAL } \\
\text { (2016) }\end{array}$ & & \\
\hline $\begin{array}{l}\text { Computer and Electronic } \\
\text { Products }\end{array}$ & 18.46 & 5.30 & 17.36 & 10.88 & 5.70 & 16.11 & 3.41 & 146.12 & 2.02 & 0.84 & 0.16 & 2.15 & 3.91 & 15.06 \\
\hline Agriculture & -1.88 & 9.65 & 4.86 & 6.59 & 21.17 & 6.54 & 5.27 & 21.01 & 3.42 & 1.97 & 0.42 & 0.73 & 3.13 & 3.53 \\
\hline Information & 0.57 & 4.01 & 4.54 & -0.59 & 2.02 & 4.04 & 43.23 & 120.14 & 2.85 & 2.24 & 2.87 & 4.72 & 4.83 & 4.55 \\
\hline Manufacturing & 1.96 & 0.36 & 3.80 & 2.53 & 1.31 & 2.72 & 36.17 & 72.07 & 18.76 & 9.92 & 15.76 & 12.51 & 2.95 & 2.43 \\
\hline Wholesale & 5.12 & -0.03 & 3.51 & 4.81 & -0.01 & 2.61 & 40.97 & 78.52 & 5.58 & 4.70 & 5.31 & 6.47 & 4.59 & 3.72 \\
\hline Mining & 5.65 & 2.47 & 2.87 & 19.86 & 8.92 & 3.45 & 96.00 & 148.51 & 0.81 & 0.54 & 1.81 & 1.39 & 5.74 & 2.36 \\
\hline FI & 5.56 & -3.88 & 2.60 & 0.31 & -4.66 & 2.35 & 49.46 & 88.89 & 5.27 & 4.93 & 6.06 & 7.68 & 5.65 & 3.42 \\
\hline Retail & 1.56 & 2.96 & 2.24 & 2.15 & 1.76 & 1.85 & 21.40 & 34.25 & 13.97 & 12.71 & 6.95 & 7.62 & 3.98 & 3.07 \\
\hline RE & 0.54 & 1.60 & 1.60 & -2.84 & -2.14 & 1.01 & 45.62 & 58.83 & 1.74 & 1.72 & 1.84 & 1.77 & 5.00 & 2.51 \\
\hline Utilities & -3.00 & 4.42 & 0.91 & -1.72 & 7.32 & 1.79 & 90.67 & 137.70 & 0.78 & 0.45 & 1.65 & 1.08 & 2.71 & 0.08 \\
\hline Transport_Warehousing & 3.47 & -2.02 & 0.80 & 2.40 & -0.72 & 0.19 & 51.84 & 54.02 & 3.68 & 4.02 & 4.44 & 3.81 & 4.64 & 2.32 \\
\hline Business Services & -2.49 & 0.05 & 0.48 & -0.94 & -0.48 & 0.82 & 61.67 & 75.87 & 11.50 & 16.09 & 16.47 & 21.38 & 5.82 & 2.89 \\
\hline Accomodation_Food & -1.82 & -1.71 & 0.05 & -1.86 & -2.47 & -0.09 & 22.86 & 22.19 & 8.64 & 10.76 & 4.59 & 4.18 & 5.18 & 1.97 \\
\hline Entertainment & -5.57 & -0.77 & -0.31 & -3.41 & -0.71 & 0.30 & 38.67 & 41.48 & 1.20 & 1.81 & 1.08 & 1.31 & 5.45 & 2.46 \\
\hline Education_Health & -2.49 & -0.68 & -0.56 & -2.47 & -0.90 & -0.31 & 55.82 & 51.47 & 11.69 & 18.17 & 15.15 & 16.37 & 5.61 & 2.26 \\
\hline Other Services & -1.91 & -0.43 & -0.56 & -1.52 & -1.32 & -0.03 & 43.05 & 42.54 & 4.52 & 4.57 & 4.52 & 3.40 & 3.94 & 0.63 \\
\hline Construction & 1.74 & -0.76 & -0.85 & 2.12 & -0.71 & -1.37 & 85.58 & 59.18 & 5.58 & 5.40 & 11.10 & 5.59 & 4.80 & 0.16 \\
\hline
\end{tabular}

Table 2a: Total household incomes by source and stagnant and dynamic sectors (trillions of 2014 dollars)

\begin{tabular}{|c|c|c|c|c|c|c|c|c|c|c|}
\hline & \multicolumn{2}{|c|}{ Wages } & \multicolumn{2}{|c|}{ Non-wage } & \multicolumn{2}{|c|}{ Transfers } & \multicolumn{2}{|c|}{ Financial } & \multicolumn{2}{|c|}{ Totals } \\
\hline & Stag. & Dyn. & Stag. & Dyn. & Stag. & Dyn. & Stag & Dyn. & Stag. & Dyn. \\
\hline Low & 1.2 & 1.0 & 0.1 & 0.2 & 1.0 & 0.9 & 0.1 & 0.1 & 2.4 & 2.2 \\
\hline Middle & 3.5 & 2.8 & 0.4 & 0.5 & 0.4 & 0.2 & 0.5 & 0.4 & 4.8 & 3.9 \\
\hline High & \multicolumn{2}{|c|}{0.8} & \multicolumn{2}{|c|}{1.2} & & & \multicolumn{2}{|c|}{0.8} & \multicolumn{2}{|c|}{2.8} \\
\hline
\end{tabular}

Table 2b: Mean incomes per household by source and stagnant and dynamic sectors (thousands of 2014 dollars)

\begin{tabular}{|l|l|l|l|l|l|l|l|l|l|l|}
\hline & \multicolumn{2}{|c|}{ Wages } & \multicolumn{2}{c|}{ Non-wage } & \multicolumn{2}{c|}{ Transfers } & \multicolumn{2}{c|}{ Financial } & \multicolumn{2}{c|}{ Totals } \\
\hline & Stag. & Dyn. & Stag. & Dyn. & Stag. & Dyn. & Stag. & Dyn. & Stag. & Dyn. \\
\hline Low & 27 & 34 & 2 & 7 & 22 & 31 & 2 & 3 & 53 & 75 \\
\hline Middle & 119 & 150 & 14 & 27 & 14 & 11 & 17 & 21 & 164 & 209 \\
\hline High & \multicolumn{2}{c}{667} & \multicolumn{2}{c|}{1000} & & \multicolumn{2}{c|}{667} & \multicolumn{2}{c|}{2334} \\
\hline
\end{tabular}


Figure 3: Productivity levels (Sectoral real VA / number of employees)
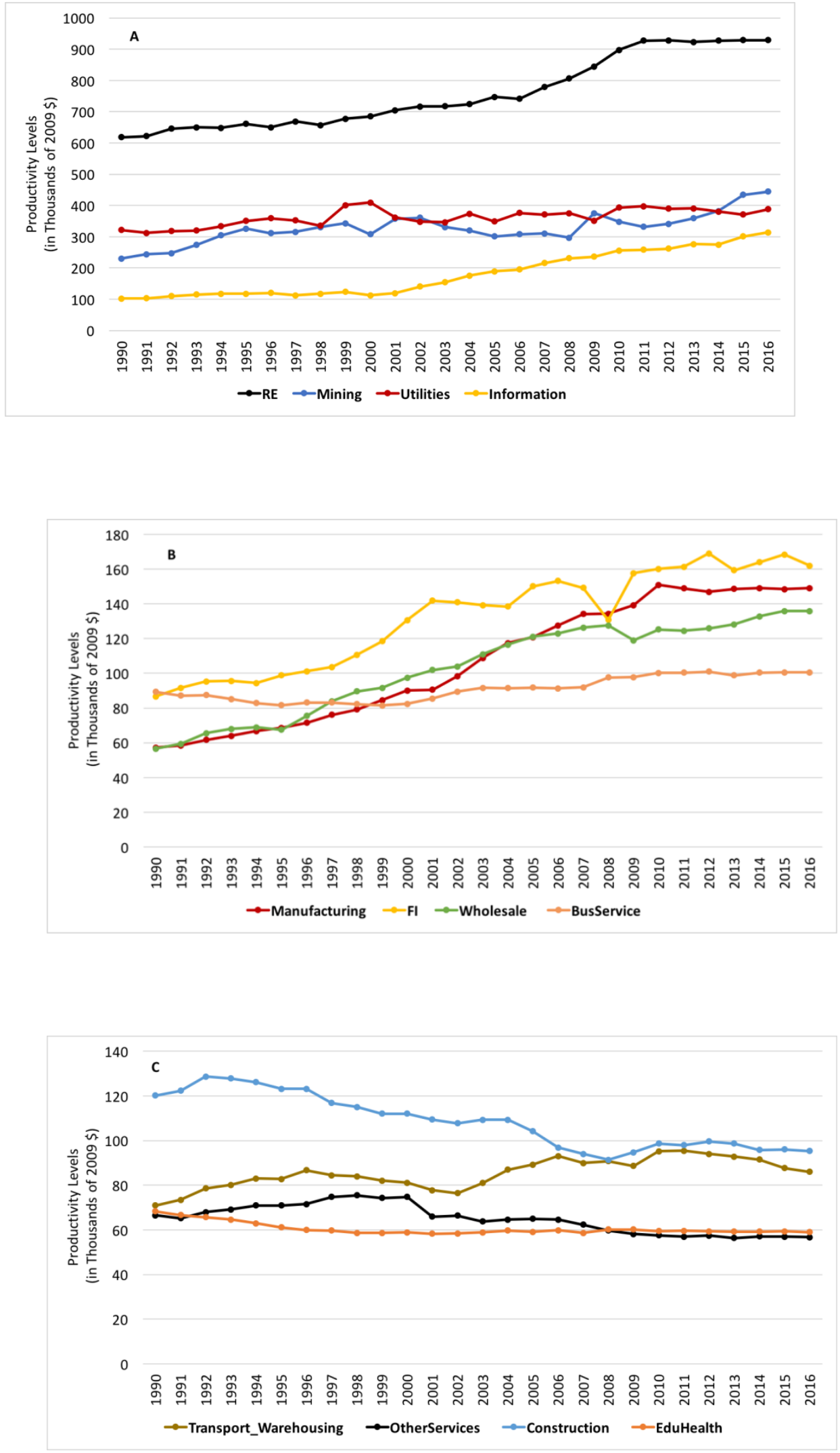


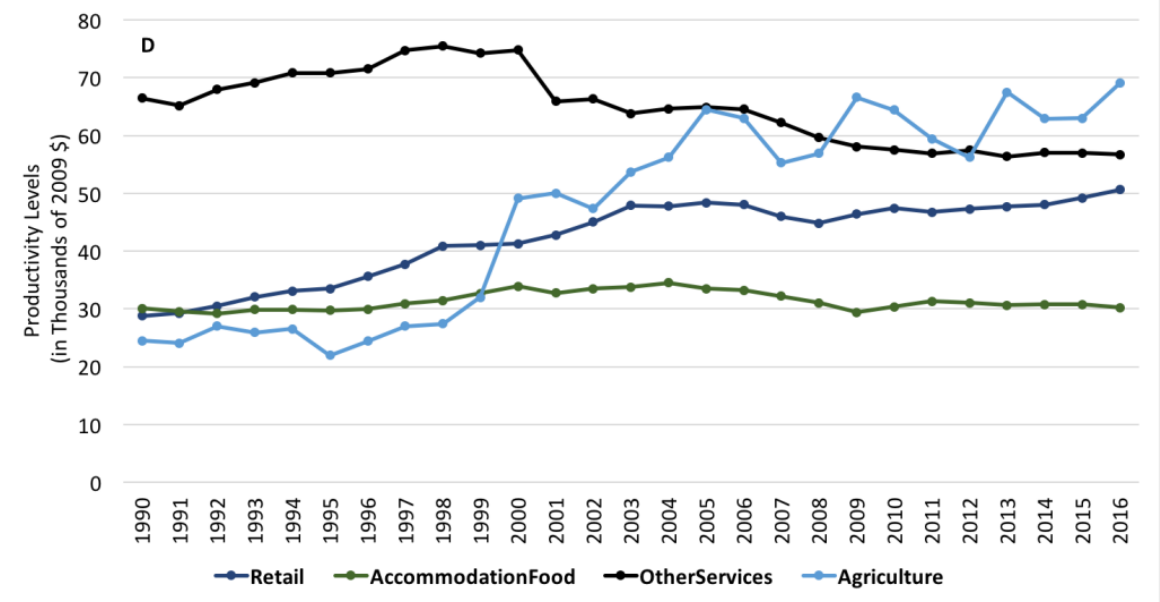


Figure 4: Decomposition of labor productivity growth (using double deflated output levels)

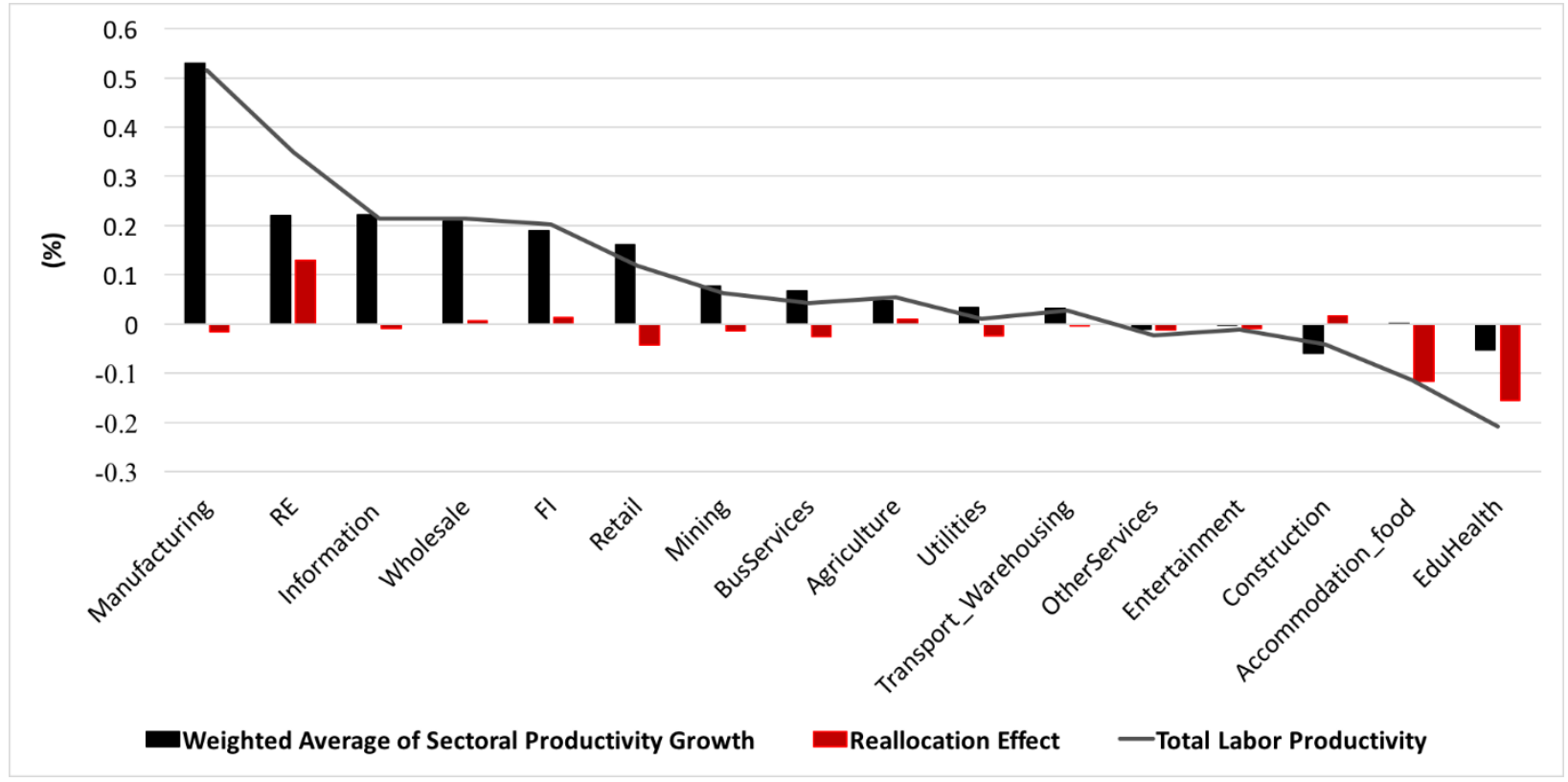


Figure 5a: Employment share decomposition

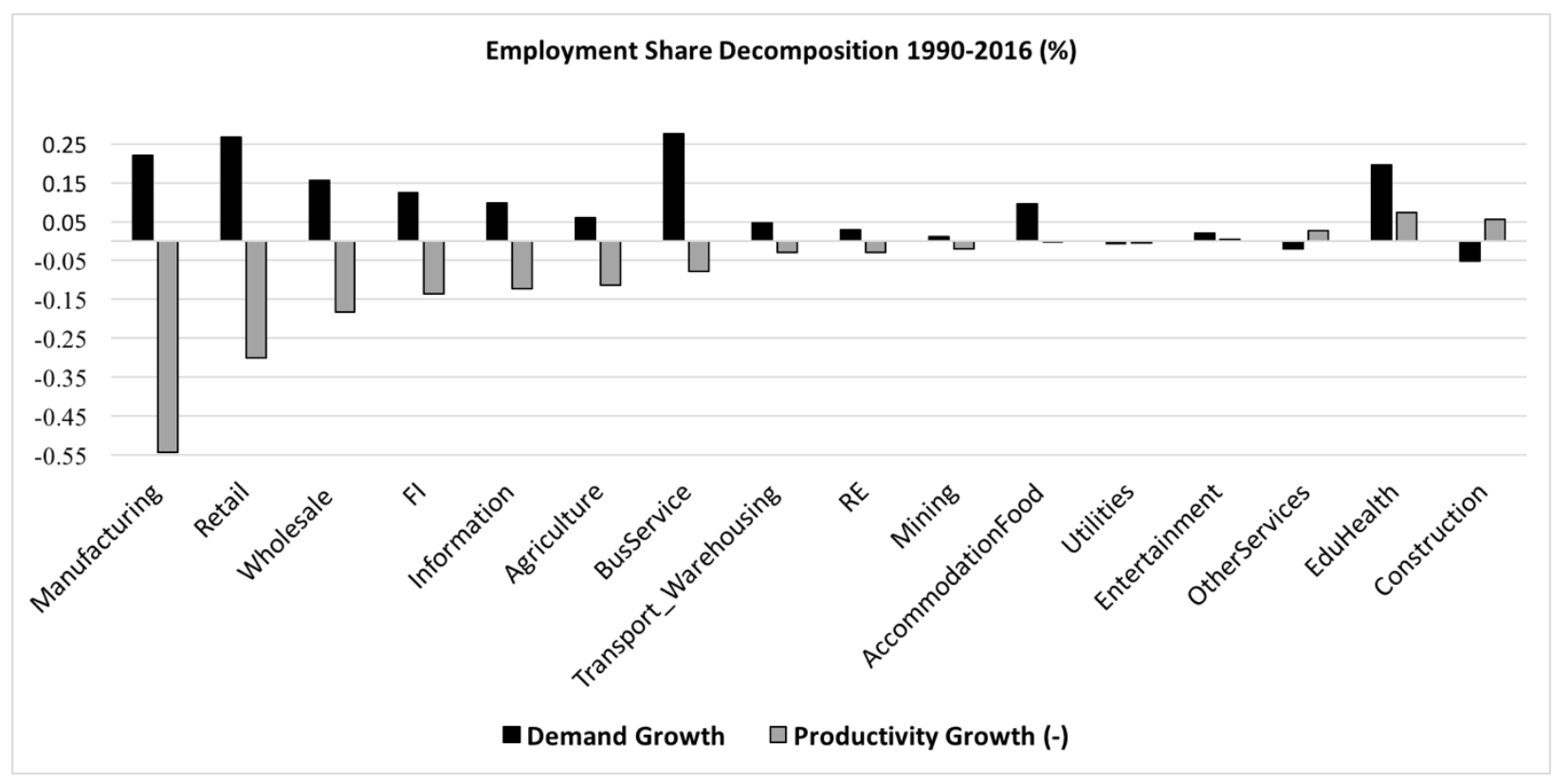

Figure 5b: Employment share growth (Demand growth + productivity growth from Figure 4a)

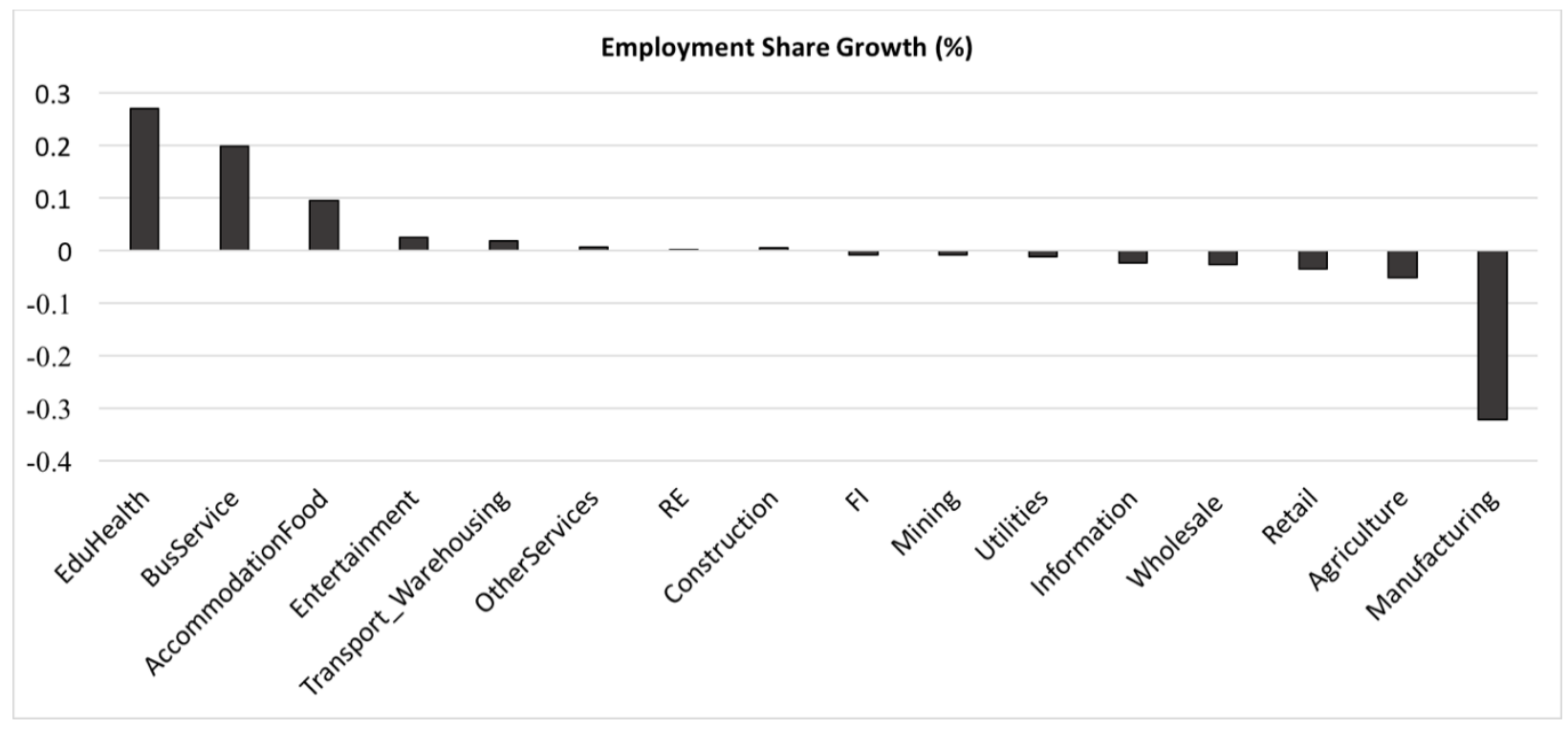


Figure 6: Effects of an upward shift of productivity growth when the dynamic sector is not strongly profit-led

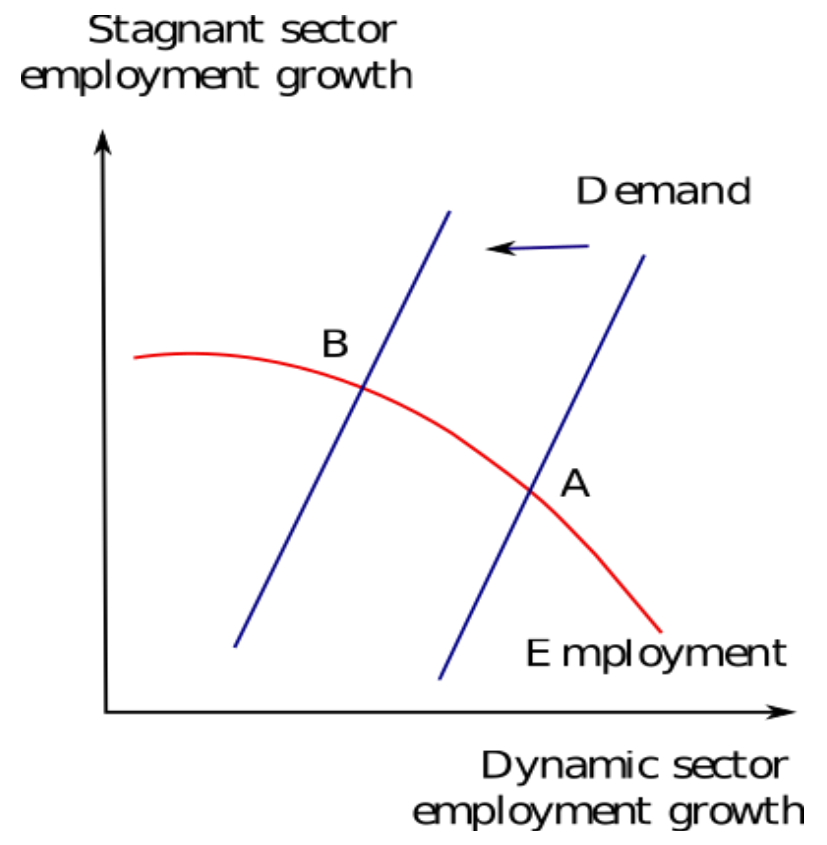

